\title{
RESPONSE OF TUBEROSE (POLIANTHES TUBEROSA L.) PLANTS TO CHITOSAN AND SEAWEED FOLIAR APPLICATION
}

\author{
W.M.F. Abd-El-Hady \\ Ornamental Plants and Landscape Gardening Res. Dept., Hort. Res. Inst., ARC, Giza, Egypt
}

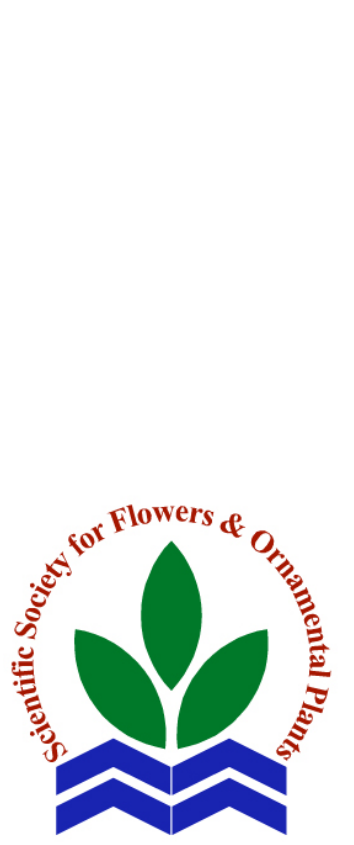

Scientific J. Flowers \& Ornamental Plants, 7(2):153-161 (2020).

Received:

27/5/2020

Accepted: $16 / 6 / 2020$

ABSTRACT: Chitosan and seaweed extract are natural stimulants that are used to improve plant growth and flowering. Therefore, two pot experiments on tuberose plants were conducted during the two consecutive seasons of 2017 and 2018 at Horticulture Research Station at Mansoura, Dakahlia Governorate, Egypt. The aim of the study was to evaluate the response of tuberose plant (single flowers known as Balady variety) to different concentrations of chitosan (CHT) and seaweed extract (SWE) rates on growth, flowering, bulb production and some chemical constituents. Tuberose plant was sprayed six times per season with different concentrations and rates of natural stimulants under study i.e. T1 (control), T2 (20 ppm CHT), T3 (40 ppm CHT), T4 (60 ppm CHT), T5 $\left(0.5 \mathrm{~cm}^{3} / \mathrm{l} \mathrm{SWE}\right), \mathrm{T} 6\left(1.0 \mathrm{~cm}^{3} / \mathrm{l} \mathrm{SWE}\right), \mathrm{T} 7$ (1.5 $\mathrm{cm}^{3} / \mathrm{l} \mathrm{SWE}$ ), T8 (20 ppm CHT $\left.+0.5 \mathrm{~cm}^{3} / \mathrm{l} \mathrm{SWE}\right)$, T9 (40 ppm CHT + $\left.1.0 \mathrm{~cm}^{3} / \mathrm{l} \mathrm{SWE}\right)$ and T10 (60 ppm CHT $\left.+1.5 \mathrm{~cm}^{3} / \mathrm{l} \mathrm{SWE}\right)$. These ten treatments were laid out in a randomized complete block design (RCBD) with three replicates. Generally, chitosan or/and seaweed extract treated tuberose showed significant increase $(\mathrm{p}<0.05)$ in plant growth, flowering and bulb production. Chitosan at higher concentration plus the higher rate of seaweed extract T10 (60 ppm $\mathrm{CHT}+1.5 \mathrm{~cm}^{3} / \mathrm{l} \mathrm{SWE}$ ) increased the plant height, leaf number per plant and leaf width as well as number of florets/spike, spike length, rachis length and spike fresh weight. In confirmation of this, the same treatment (T10) resulted in higher values of bulb diameter and dry weight of bulb compared to the other treatments under study and unsprayed plants. In most cases, total nitrogen, total phosphorus and potassium percentages in the leaves and bulbs as well as total chlorophyll in the leaves were significantly increased by using T10 followed by T4 and T9 compared to the other ones under study. Moreover, natural stimulants (chitosan and seaweed extract) should be frequently applied in the farms to get the best growth and flowering of the tuberose plants.

Key words: Polianthes tuberosa, chitosan, seaweed extract, growth, flowering, chlorophyll.

\section{INTRODUCTION}

Tuberose (Polianthes tuberosa L.) is considered as one of the most important and popular cut flowers all over the world as well as in Egypt. It belongs to family Amaryllidacea. It has adequate economic chance for cut flower commerce and volatile oil industry (Alan et al., 2007). Tuberose plants are used as ornamental garden plants with beautiful flowers. Its flowers are used in perfume industry and is used also as emetic and diuretic activity. Bulbs are utilized for curing pustules in babies (Rammamurthy et al., 2010). Flower spikes of tuberose have varied utilizations in vases and bouquets, whilst large flowers are used for producing 
garlands and other floral arrangements (Deshmukh, 2012).

Actually, natural stimulants consisting in a variety of substances such as chitosan and seaweed extract that are utilized to increase plant growth and get better quality of their yields are of great benefit in horticulture and agriculture production (Calvo et al., 2014). Chitosan is a natural polymer with a polycationic kind, which has many usages in agriculture practices e.g., as an elicitor, soil modifier, films and fungicide (Deepmala et al., 2014). Moreover, it holds nitrogen in the basal unit of its formularization $\left(\mathrm{C}_{11} \mathrm{H}_{17} \mathrm{O}_{7} \mathrm{~N}_{2}\right)$, which is considered one of the most serious nutritious elements in plants and soil alike (Ibraheim and Mohsen, 2015). The results from the literature point out that, when treating plants, chitosan can increase the growth, flowering and corms production of potted freesia (Salachna and Zawadzińska, 2014), improve growth and bulb yield of pineapple lily (Byczyńska, 2018) and increase the plant defense versus the attack of pathogens (Malerba and Cerana, 2018).

The usage of seaweed extract for several crops was a great significance as it contains high levels of micro elements and vitamins as well as organic matter and fatty acids and also seaweeds contain several growth promoting substances i.e. auxin, cytokinins and abscisic acid which encourage plant development and growth and increase plant tolerance to different environmental stresses (Zhang et al., 2003), increase nutrient acquisition (Turan and Kose, 2004), promote total bulb yield and its components as well as content of the nitrogen percentage of onion bulb tissues (Shafeek et al., 2015) and improve bulb diameter, bulb fresh weight g/plant, total yield of garlic (Rady et al., 2018).

Therefore, the present study was designed to discover the response of tuberose plants to different concentrations of chitosan and different rates of seaweed extract on plant growth, flowering and bulb production as well as chemical contents of leaves and bulbs.

\section{MATERIAL AND METHODS}

The present study was carried out during the two consecutive seasons of 2017 and 2018 in Horticulture Research Station at Mansoura, Dakahlia Governorate, Egypt, to study the influence of foliar application of some natural stimulants (chitosan and seaweed extract) compounds on growth, flowering and bulb production as well as chemical composition of tuberose plants.

Tuberose bulbs cultivar Balady were obtained from a private nursery at ElKanater El-Khairia, Qalubia Governorate, Egypt, during the end of March. Bulbs were chosen of diameter $(4-5 \mathrm{~cm})$, where the bulbs were cleaned, washed and treated with a fungal disinfectant (called No Blight 50\% thiram), then they cured and stored for two weeks at a temperature of $7{ }^{\circ} \mathrm{C} \pm 2$. Bulbs were planted in pots of $25 \mathrm{~cm}$ diameter filled with $6 \mathrm{~kg}$ of sand:peat moss $(1: 1 \mathrm{v} / \mathrm{v})$ during $15^{\text {th }}$ April in the two seasons. Three grams of granular fertilizer of $\mathrm{N}: \mathrm{P}: \mathrm{K} ; 18: 18: 18$ were added to each plant/pot. Four doses were added monthly from June till August. After two months of planting, the tuberose plants were sprayed with natural stimulants once every 15 days, from the beginning of June till the end of August of each season (6 times sprayed on the vegetative parts). Commercial seaweeds extract product was utilized. Seaweeds extract contained nitrogen, magnesium, sulfur, boron, molybdenum and alganic acid at $(6,6,9.6,0.5,0.26$ and $4 \%$, respectively) as well as some organic matter and plant hormones.

The experiment included 10 treatments from natural stimulants as follows:
T1. Foliar application with tap water (control).

T2. Foliar application with chitosan (CHT) at $20 \mathrm{ppm}$ concentration.

T3. Foliar application with CHT at $40 \mathrm{ppm}$.

T4. Foliar application with CHT at $60 \mathrm{ppm}$.

T5. Foliar application with seaweed extract (SWE) at $0.5 \mathrm{~cm}^{3} / \mathrm{l}$.

T6. Foliar application with SWE at $1.0 \mathrm{~cm}^{3} / \mathrm{l}$.

T7. Foliar application with SWE at $1.5 \mathrm{~cm}^{3} / 1$. 
T8. Foliar application with at $20 \mathrm{ppm}$ CHT + $0.5 \mathrm{~cm}^{3} \mathrm{SWE} / \mathrm{l}$.

T9. Foliar application with 40 ppm CHT + $1.0 \mathrm{~cm}^{3} \mathrm{SWE} / \mathrm{l}$.

T10. Foliar application with $60 \mathrm{ppm}$ CHT + $1.5 \mathrm{~cm}^{3} \mathrm{SWE} / \mathrm{l}$.

These ten treatments were laid out in a randomized complete block design (RCBD), with three replicates.

\section{Data recorded:}

Plant growth: after 65 days from planting date, plant height $(\mathrm{cm})$ and number of leaves/plant as well as leaf width $(\mathrm{cm})$ were recorded.

Flowering parameters: flowering date (days), number of florets/spike, spike length (cm), rachis length $(\mathrm{cm})$ and fresh weight of flowering spike (g) were determined.

Bulb production: diameter of produced bulb (cm) and it's dry weight bulb (g).

Chemical constituents: total nitrogen, total phosphorus and potassium percentages in dried leaves and bulbs were determined according to Chapman and Pratt (1978). Also, total chlorophyll and carotenoids contents in tuberose fresh leaves were analyzed according to AOAC (1990).

\section{Statistical analysis:}

Data were statistically analyzed using the analysis of variance according to Snedecor and Cochran (1980). Least significance difference (LSD) was used to differentiate means at 5\% level of probability. The means were compared using computer program of Statistix version 9 (Analytical software, 2008).

\section{RESULTS AND DISCUSSION}

\section{Plant growth:}

It is quite clear from data presented in Table (1) that, plant height, number of leaves per plant and leaf width of Polianthes tuberosa gradually increased by increase the concentrations of CHT and rates of SWE during both seasons. All chitosan and seaweed extract treatments significantly increased tuberose growth parameters compared to control. The tallest plants were achieved with $60 \mathrm{ppm} \mathrm{CHT}+1.5 \mathrm{~cm}^{3} \mathrm{SWE} / \mathrm{l}$ in the two seasons. The increases in number of leaves per plant were about 37.35 and $43.64 \%$ for $60 \mathrm{ppm}$ CHT $+1.5 \mathrm{~cm}^{3} \mathrm{SWE} / \mathrm{l}$, 31.35 and $32.36 \%$ for $60 \mathrm{ppm}$ CHT and 13.43 and $15.46 \%$ for $1.5 \mathrm{~cm}^{3}$ SWE/l over the control in $1^{\text {st }}$ and $2^{\text {nd }}$ seasons, respectively. However, Salachna and Zawadzińska (2014) reported that treating freesia corms with chitosan solution before planting had a stimulatory influence on the plant height and the number of leaves. ElGamal and Ahmed (2016) indicated that

Table 1. Influence of chitosan (CHT) and seaweed extract (SWE) on plant height (cm), number of leaves/plant and leaf width $(\mathrm{cm})$ of Polianthus tuberosa plant during 2017 and 2018 seasons.

\begin{tabular}{|c|c|c|c|c|c|c|}
\hline \multirow[t]{2}{*}{ Treatments } & \multicolumn{2}{|c|}{$\begin{array}{l}\text { Plant height } \\
\text { (cm) }\end{array}$} & \multicolumn{2}{|c|}{$\begin{array}{c}\text { Number of } \\
\text { leaves/plant }\end{array}$} & \multicolumn{2}{|c|}{$\begin{array}{l}\text { Leaf width } \\
\text { (cm) }\end{array}$} \\
\hline & 2017 & 2018 & 2017 & 2018 & 2017 & 2018 \\
\hline Control & 45.53 & 50.27 & 22.33 & 23.67 & 0.91 & 1.00 \\
\hline 20 ppm CHT & 54.93 & 56.20 & 25.67 & 25.67 & 1.17 & 1.33 \\
\hline 40 ppm CHT & 59.00 & 60.50 & 26.67 & 27.00 & 1.41 & 1.52 \\
\hline 60 ppm CHT & 69.13 & 70.40 & 29.33 & 31.33 & 1.72 & 1.88 \\
\hline $0.5 \mathrm{~cm}^{3} / 1 \mathrm{SWE}$ & 49.53 & 52.00 & 25.33 & 25.67 & 1.01 & 1.18 \\
\hline $1.0 \mathrm{~cm}^{3} / 1 \mathrm{SWE}$ & 54.40 & 55.53 & 24.67 & 25.33 & 1.36 & 1.56 \\
\hline $1.5 \mathrm{~cm}^{3} / 1 \mathrm{SWE}$ & 59.33 & 61.00 & 25.33 & 27.33 & 1.44 & 1.56 \\
\hline $20 \mathrm{ppm}$ CHT $+0.5 \mathrm{~cm}^{3} / 1 \mathrm{SWE}$ & 62.93 & 64.70 & 26.67 & 26.00 & 1.56 & 1.62 \\
\hline $40 \mathrm{ppm} \mathrm{CHT}+1.0 \mathrm{~cm}^{3} / \mathrm{l} \mathrm{SWE}$ & 66.37 & 67.57 & 29.67 & 31.33 & 1.70 & 1.80 \\
\hline $60 \mathrm{ppm} \mathrm{CHT}+1.5 \mathrm{~cm}^{3} / \mathrm{l} \mathrm{SWE}$ & 70.70 & 71.77 & 30.67 & 34.00 & 1.88 & 2.11 \\
\hline LSD at $5 \%$ & 2.44 & 3.68 & 2.12 & 2.19 & 0.21 & 0.17 \\
\hline
\end{tabular}

CHT= chitosan; SWE= seaweed extract. 
foliar application of chitosan at all utilized concentrations (20, 40, 60 and 80 ppm) significantly advanced the vegetative growth characters of coriander in terms of plant height and number of branches per plant.

The presence of several nutrients, growth hormones, vitamins and other constituents in the seaweed extract might be very considerable beneficial to the crops but their level should be allocated to improve growth and productivity (Crouch et al., 1992). Foliar application of seaweeds extract gave the highest stimulatory effect on onion plant growth characters i.e. plant length and number of leaves as well as fresh and dry weight of leaves (Shafeek et al., 2015).

\section{Flowering parameters:}

Data of both seasons presented in Tables (2 and 3) indicate that, the earliest flowering resulted significantly from applying $60 \mathrm{ppm}$ $\mathrm{CHT}+1.5 \mathrm{~cm}^{3} \mathrm{SWE} / \mathrm{l}$ treatment as occurred after 69.33 and 69.00 days followed by 40 $\mathrm{ppm} \mathrm{CHT}+1.0 \mathrm{~cm}^{3} \mathrm{SWE} / \mathrm{l}$ treatment after 71.00 and 69.67 days. However, in the control treatment flowering occurred after

Table 2. Influence of chitosan (CHT) and seaweed extract (SWE) on number of days to flowering, number of florets/spike and spike length $(\mathrm{cm})$ of Polianthus tuberosa plant during 2017 and 2018 seasons.

\begin{tabular}{|c|c|c|c|c|c|c|}
\hline \multirow[t]{2}{*}{ Treatments } & \multicolumn{2}{|c|}{$\begin{array}{c}\text { Number of days to } \\
\text { flowering }\end{array}$} & \multicolumn{2}{|c|}{$\begin{array}{c}\text { Number of } \\
\text { florets/spike }\end{array}$} & \multicolumn{2}{|c|}{ Spike length $(\mathrm{cm})$} \\
\hline & 2017 & 2018 & 2017 & 2018 & 2017 & 2018 \\
\hline Control & 93.33 & 92.00 & 25.33 & 26.33 & 52.97 & 52.00 \\
\hline 20 ppm CHT & 83.00 & 79.33 & 32.33 & 34.00 & 57.93 & 58.77 \\
\hline 40 ppm CHT & 79.00 & 76.67 & 39.00 & 41.33 & 60.33 & 61.37 \\
\hline $60 \mathrm{ppm}$ CHT & 70.00 & 70.00 & 45.67 & 46.67 & 68.53 & 67.87 \\
\hline $0.5 \mathrm{~cm}^{3} / \mathrm{l} \mathrm{SWE}$ & 88.33 & 86.67 & 28.00 & 28.67 & 55.50 & 57.23 \\
\hline $1.0 \mathrm{~cm}^{3} / 1 \mathrm{SWE}$ & 84.33 & 80.00 & 29.33 & 30.67 & 56.57 & 57.73 \\
\hline $1.5 \mathrm{~cm}^{3} / 1 \mathrm{SWE}$ & 81.67 & 78.67 & 32.00 & 34.33 & 59.23 & 59.60 \\
\hline $20 \mathrm{ppm}$ CHT $+0.5 \mathrm{~cm}^{3} / 1 \mathrm{SWE}$ & 77.00 & 75.67 & 40.00 & 41.67 & 59.67 & 60.50 \\
\hline $40 \mathrm{ppm} \mathrm{CHT}+1.0 \mathrm{~cm}^{3} / 1 \mathrm{SWE}$ & 71.00 & 69.67 & 44.33 & 46.67 & 68.67 & 67.70 \\
\hline $60 \mathrm{ppm}$ CHT+1.5 $\mathrm{cm}^{3} / \mathrm{l}$ SWE & 69.33 & 69.00 & 45.67 & 47.67 & 65.80 & 64.13 \\
\hline LSD at $5 \%$ & 3.41 & 2.58 & 1.71 & 1.65 & 1.63 & 1.47 \\
\hline
\end{tabular}

CHT= chitosan; SWE = seaweed extract.

Table 3. Influence of chitosan (CHT) and seaweed extract (SWE) on rachis length (cm) and fresh weight of spike (g) of Polianthus tuberosa plant during 2017 and 2018 seasons.

\begin{tabular}{|c|c|c|c|c|}
\hline \multirow{2}{*}{ Treatments } & \multicolumn{2}{|c|}{ Rachis length (cm) } & \multicolumn{2}{|c|}{ Fresh weight of spike (g) } \\
\hline & 2017 & 2018 & 2017 & 2018 \\
\hline Control & 21.20 & 21.93 & 41.47 & 42.33 \\
\hline 20 ppm CHT & 27.33 & 28.93 & 46.27 & 47.70 \\
\hline 40 ppm CHT & 27.83 & 29.17 & 48.93 & 50.00 \\
\hline 60 ppm CHT & 29.50 & 32.17 & 53.23 & 54.30 \\
\hline $0.5 \mathrm{~cm}^{3} / 1 \mathrm{SWE}$ & 22.80 & 24.93 & 44.83 & 45.13 \\
\hline $1.0 \mathrm{~cm}^{3} / 1 \mathrm{SWE}$ & 25.37 & 26.37 & 46.27 & 46.83 \\
\hline $1.5 \mathrm{~cm}^{3} / \mathrm{l} \mathrm{SWE}$ & 27.07 & 27.73 & 46.90 & 47.57 \\
\hline $20 \mathrm{ppm}$ CHT+0.5 $\mathrm{cm}^{3} / \mathrm{l} \mathrm{SWE}$ & 28.37 & 29.20 & 50.97 & 51.97 \\
\hline $40 \mathrm{ppm}$ CHT $+1.0 \mathrm{~cm}^{3} / \mathrm{l} \mathrm{SWE}$ & 29.40 & 31.07 & 54.70 & 56.40 \\
\hline $60 \mathrm{ppm}$ CHT $+1.5 \mathrm{~cm}^{3} / \mathrm{l}$ SWE & 30.10 & 33.80 & 57.63 & 58.77 \\
\hline LSD at $5 \%$ & 1.93 & 1.68 & 2.27 & 2.14 \\
\hline
\end{tabular}

CHT= chitosan; SWE= seaweed extract. 
93.33 and 92.00 days from planting in the first and second seasons, respectively. Furthermore, all natural stimulants treatments under study significantly increased number of florets per spike, spike length, rachis length and fresh weight of tuberose spike compared to control in both seasons. The highest values in this concern were recorded by the treatments of T10 (60 ppm CHT + $1.5 \mathrm{~cm}^{3}$ SWE/l), T4 (60 ppm CHT) and T9 (40 ppm CHT $+1.0 \mathrm{~cm}^{3}$ SWE/l) compared to the other ones under study. The increases in fresh weight of spike were about 38.97 and $38.84 \%$ for $60 \mathrm{ppm}$ $\mathrm{CHT}+1.5 \mathrm{~cm}^{3} \mathrm{SWE} / \mathrm{l}$ over the control in $1^{\text {st }}$ and $2^{\text {nd }}$ seasons, respectively. As a result of coating Ornithogalum saundersiae bulbs in a chitosan solution before planting the plants were higher and flowered earlier (Salachna et al., 2015). Also, application of chitosan enhanced inflorescence length of pineapple lily, inflorescence width and began flowering earlier than the control ones (Byczyńska, 2018). Furthermore, El-Sayed et al. (2018) found that adding seaweed extract at $1 \%$ revealed significant increase in the flower diameter of dahlia plants, duration and dry weight of flower while a significant increase in number of days needed to reach flowering was recorded with all fertilizer treatments in both seasons. The maximum flowering duration of jasmine (Jasminum sambac Ait.) was recorded when seaweed extract was used as foliar spray at 5\% concentration (Sowmiya and Karuppaiah, 2019).

\section{Bulb production:}

Data listed in Table (4) suggest that, the best treatment increasing diameter and dry weight of produced bulb was that $60 \mathrm{ppm}$ $\mathrm{CHT}+1.5 \mathrm{~cm}^{3} \mathrm{SWE} / \mathrm{l}$ with significant difference between the other treatments under study in both seasons. Generally, all concentrations of chitosan and rates of seaweed extract significantly increased tuberose bulb production compared to control. Increasing CHT concentrations and SWE rates gradually increased the abovementioned parameters in the 2017 and 2018 seasons. Also, Ramos-Garcia et al. (2009) demonstrated that the production of gladiolus corms increased as a result of utilizing the chitosan as natural stimulant. The highest increase in the corm weight was recorded as a result of treating freesia plants with chitosan (Salachna and Zawadzińska, 2014). However, soaking garlic bulbs in seaweed extra at a rate of $3 \mathrm{ml} / \mathrm{l}$ can be recommended for obtaining higher bulb (Rady et al., 2018).

\section{Chemical constituents:}

As shown in Table (5) that, total nitrogen, total phosphorus and potassium

Table 4. Influence of chitosan (CHT) and seaweed extract (SWE) on the produced bulb diameter $(\mathrm{cm})$ and bulb dry weight $(\mathrm{g})$ of Polianthus tuberosa plant during 2017 and 2018 seasons.

\begin{tabular}{|c|c|c|c|c|}
\hline \multirow{2}{*}{ Treatments } & \multicolumn{2}{|c|}{ Produced bulb diameter $(\mathrm{cm})$} & \multicolumn{2}{|c|}{ Produced bulb dry weight (g) } \\
\hline & 2017 & 2018 & 2017 & 2018 \\
\hline Control & 1.58 & 1.64 & 16.47 & 16.98 \\
\hline 20 ppm CHT & 2.02 & 2.19 & 19.85 & 21.33 \\
\hline 40 ppm CHT & 2.23 & 2.30 & 22.13 & 23.27 \\
\hline 60 ppm CHT & 2.34 & 2.42 & 23.12 & 25.47 \\
\hline $0.5 \mathrm{~cm}^{3} / 1 \mathrm{SWE}$ & 1.68 & 1.72 & 17.31 & 17.96 \\
\hline $1.0 \mathrm{~cm}^{3} / 1 \mathrm{SWE}$ & 1.72 & 1.75 & 18.77 & 20.74 \\
\hline $1.5 \mathrm{~cm}^{3} / \mathrm{l} \mathrm{SWE}$ & 1.84 & 1.90 & 21.36 & 22.71 \\
\hline 20 ppm CHT+0.5 $\mathrm{cm}^{3} / \mathrm{l}$ SWE & 2.19 & 2.25 & 22.00 & 24.17 \\
\hline $40 \mathrm{ppm}$ CHT $+1.0 \mathrm{~cm}^{3} / \mathrm{l}$ SWE & 2.37 & 2.45 & 23.27 & 25.48 \\
\hline $60 \mathrm{ppm}$ CHT+1.5 $\mathrm{cm}^{3} / \mathrm{l}$ SWE & 2.51 & 2.67 & 25.58 & 28.90 \\
\hline LSD at $5 \%$ & 0.07 & 0.05 & 1.26 & 1.12 \\
\hline
\end{tabular}

CHT= chitosan; SWE= seaweed extract. 
Table 5. Influence of chitosan (CHT) and seaweed extract (SWE) on total nitrogen, total phosphorus and potassium percentages in the leaves of Polianthus tuberosa plant during 2017 and 2018 seasons.

\begin{tabular}{|c|c|c|c|c|c|c|}
\hline \multirow{2}{*}{ Treatments } & \multicolumn{2}{|c|}{$\begin{array}{c}\text { Total nitrogen } \\
(\%)\end{array}$} & \multicolumn{2}{|c|}{$\begin{array}{c}\text { Total phosphorus } \\
(\%)\end{array}$} & \multicolumn{2}{|c|}{$\begin{array}{c}\text { Potassium } \\
\text { (\%) }\end{array}$} \\
\hline & 2017 & 2018 & 2017 & 2018 & 2017 & 2018 \\
\hline Control & 1.633 & 1.707 & 0.198 & 0.208 & 2.043 & 2.147 \\
\hline 20 ppm CHT & 2.097 & 2.200 & 0.225 & 0.239 & 2.160 & 2.240 \\
\hline 40 ppm CHT & 2.220 & 2.253 & 0.236 & 0.256 & 2.227 & 2.243 \\
\hline 60 ppm CHT & 2.333 & 2.400 & 0.268 & 0.284 & 2.353 & 2.403 \\
\hline $0.5 \mathrm{~cm}^{3} / 1 \mathrm{SWE}$ & 1.777 & 1.830 & 0.214 & 0.220 & 2.090 & 2.187 \\
\hline $1.0 \mathrm{~cm}^{3} / 1 \mathrm{SWE}$ & 1.857 & 1.970 & 0.235 & 0.238 & 2.210 & 2.247 \\
\hline $1.5 \mathrm{~cm}^{3} / \mathrm{l} \mathrm{SWE}$ & 2.093 & 2.177 & 0.242 & 0.258 & 2.263 & 2.283 \\
\hline $20 \mathrm{ppm}$ CHT+0.5 $\mathrm{cm}^{3} / \mathrm{l}$ SWE & 2.233 & 2.273 & 0.256 & 0.268 & 2.337 & 2.397 \\
\hline $40 \mathrm{ppm} \mathrm{CHT}+1.0 \mathrm{~cm}^{3} / \mathrm{l} \mathrm{SWE}$ & 2.370 & 2.450 & 0.269 & 0.297 & 2.403 & 2.553 \\
\hline $60 \mathrm{ppm} \mathrm{CHT}+1.5 \mathrm{~cm}^{3} / \mathrm{l} \mathrm{SWE}$ & 2.630 & 2.763 & 0.324 & 0.346 & 2.587 & 2.683 \\
\hline LSD at $5 \%$ & 0.109 & 0.054 & 0.029 & 0.026 & 0.071 & 0.054 \\
\hline
\end{tabular}

CHT= chitosan; SWE $=$ seaweed extract.

percentages in tuberose leaves were significantly increased with all treatments of chitosan and seaweed extract compared to control in both seasons. The highest values in this respect were obtained by the treatment of T10 (60 ppm CHT $+1.5 \mathrm{~cm}^{3}$ $\mathrm{SWE} / \mathrm{l})$. The increases in potassium percentage in the leaves was about 26.63 and $24.97 \%$ for T10 over the control in $1^{\text {st }}$ and $2^{\text {nd }}$ seasons, respectively. The same trend was achieved with the same treatment (T10) regarding $\mathrm{N}, \mathrm{P}$ and $\mathrm{K}$ percentages in tuberose bulbs in the first and second seasons Table (6). The increases in total nitrogen percentage in tuberose bulbs were about 43.72 and $46.67 \%$ for T10 over the control in $1^{\text {st }}$ and $2^{\text {nd }}$ seasons, respectively. The lowest values in NPK percentages of bulbs were noticed when tuberose plant sprayed with tap water (control treatment) compared to the tested treatments under study. In addition, spraying tuberose plants 6 times/season with mixture of natural stimulants at $60 \mathrm{ppm}$ $\mathrm{CHT}+1.5 \mathrm{~cm}^{3} \mathrm{SWE} / \mathrm{l}$ significantly increased total chlorophyll and carotenoids contents in the leaves compared to control (sprayed with tap water) as shown in Table (7). Likewise, all treatments under study (from T2 to T10) significantly increased leaf pigments compared to control in the two seasons.

Furthermore, Dzung et al. (2011) found that as a result of spraying coffee seedlings by chitosan solutions, the content of chlorophylls and carotenoids in the leaves was increased by $46.38-73.5 \%$ in plants grown in the greenhouse when compared to the control. Treating the Eucomis bicolor plants with chitosan at $50 \mathrm{mg} / \mathrm{l}$ had the great beneficial influence on the relative chlorophyll content in the leaves (Byczyńska, 2018). Dracaena surculosa plants sprayed with chitosan contained the highest total nitrogen percentage and chlorophyll a of leaves; also, it increased with increasing the chitosan concentrations (El-Khateeb et al., 2018). Seaweed extracts (SWE) have been found to improve nutrients availability and nutrients uptake of Amaranthus tricolor from the soil (Aziz et al., 2011). Moreover, the N, $\mathrm{P}$ and $\mathrm{K}$ (\%) of the leaves of dahlia as well as the total content of chlorophyll were significantly stimulated with seaweed extract at $1 \%$ rate compared to the control (El-Sayed et al., 2018). The application of $0.5 \%$ SWE resulted in a significant increase in mineral contents (N, P, and $\mathrm{K}$ ) of onion bulbs (Abbas et al., 2020).

\section{CONCLUSION}

The above results pointed out that the tuberose growth and flowering quality as well as chemical constituents of the leaves and bulbs responded to natural stimulants 
Table 6. Influence of chitosan (CHT) and seaweed extract (SWE) on total nitrogen, total phosphorus and potassium percentages in bulbs of Polianthus tuberosa plant during 2017 and 2018 seasons.

\begin{tabular}{|c|c|c|c|c|c|c|}
\hline \multirow{2}{*}{ Treatments } & \multicolumn{2}{|c|}{$\begin{array}{c}\text { Total nitrogen } \\
\text { (\%) }\end{array}$} & \multicolumn{2}{|c|}{$\begin{array}{c}\text { Total phosphorus } \\
\text { (\%) }\end{array}$} & \multicolumn{2}{|c|}{$\begin{array}{c}\text { Potassium } \\
\text { (\%) }\end{array}$} \\
\hline & 2017 & 2018 & 2017 & 2018 & 2017 & 2018 \\
\hline Control & 1.147 & 1.200 & 0.117 & 0.135 & 1.167 & 1.213 \\
\hline 20 ppm CHT & 1.267 & 1.300 & 0.197 & 0.196 & 1.400 & 1.453 \\
\hline 40 ppm CHT & 1.327 & 1.390 & 0.200 & 0.208 & 1.487 & 1.533 \\
\hline 60 ppm CHT & 1.527 & 1.597 & 0.208 & 0.212 & 1.627 & 1.713 \\
\hline $0.5 \mathrm{~cm}^{3} / 1 \mathrm{SWE}$ & 1.237 & 1.250 & 0.173 & 0.180 & 1.213 & 1.240 \\
\hline $1.0 \mathrm{~cm}^{3} / \mathrm{l} \mathrm{SWE}$ & 1.263 & 1.273 & 0.189 & 0.192 & 1.213 & 1.250 \\
\hline $1.5 \mathrm{~cm}^{3} / 1 \mathrm{SWE}$ & 1.270 & 1.297 & 0.193 & 0.196 & 1.270 & 1.310 \\
\hline $20 \mathrm{ppm}$ CHT+0.5 $\mathrm{cm}^{3} / \mathrm{l}$ SWE & 1.460 & 1.550 & 0.193 & 0.197 & 1.533 & 1.593 \\
\hline $40 \mathrm{ppm}$ CHT $+1.0 \mathrm{~cm}^{3} / \mathrm{l} \mathrm{SWE}$ & 1.553 & 1.630 & 0.199 & 0.210 & 1.597 & 1.730 \\
\hline $60 \mathrm{ppm} \mathrm{CHT}+1.5 \mathrm{~cm}^{3} / \mathrm{l} \mathrm{SWE}$ & 1.637 & 1.760 & 0.213 & 0.219 & 1.773 & 1.887 \\
\hline LSD at $5 \%$ & 0.039 & 0.40 & 0.007 & 0.007 & 0.058 & 0.048 \\
\hline
\end{tabular}

CHT= chitosan; $\mathrm{SWE}=$ seaweed extract.

Table 7. Influence of chitosan (CHT) and seaweed extract (SWE) on total chlorophyll and carotenoids contents (mg/100 $\mathrm{g}$ as fresh weight) in leaves of Polianthus tuberosa plant during 2017 and 2018 seasons.

\begin{tabular}{|c|c|c|c|c|}
\hline \multirow[t]{2}{*}{ Treatments } & \multicolumn{2}{|c|}{$\begin{array}{l}\text { Total chlorophyll content } \\
\text { (mg/100 g as F.W.) }\end{array}$} & \multicolumn{2}{|c|}{$\begin{array}{l}\text { Carotenoids content } \\
\text { (mg/100 g as F.W.) }\end{array}$} \\
\hline & 2017 & 2018 & 2017 & 2018 \\
\hline Control & 0.363 & 0.392 & 0.246 & 0.264 \\
\hline 20 ppm CHT & 0.488 & 0.505 & 0.363 & 0.372 \\
\hline 40 ppm CHT & 0.522 & 0.554 & 0.371 & 0.381 \\
\hline 60 ppm CHT & 0.564 & 0.584 & 0.377 & 0.389 \\
\hline $0.5 \mathrm{~cm}^{3} / 1 \mathrm{SWE}$ & 0.412 & 0.424 & 0.307 & 0.325 \\
\hline $1.0 \mathrm{~cm}^{3} / 1 \mathrm{SWE}$ & 0.424 & 0.443 & 0.337 & 0.355 \\
\hline $1.5 \mathrm{~cm}^{3} / 1 \mathrm{SWE}$ & 0.484 & 0.510 & 0.366 & 0.380 \\
\hline 20 ppm CHT+0.5 cm³/l SWE & 0.539 & 0.571 & 0.333 & 0.354 \\
\hline 40 ppm CHT+1.0 $\mathrm{cm}^{3} / \mathrm{l} \mathrm{SWE}$ & 0.580 & 0.606 & 0.350 & 0.393 \\
\hline 60 ppm CHT+1.5 $\mathrm{cm}^{3} / 1 \mathrm{SWE}$ & 0.573 & 0.625 & 0.386 & 0.425 \\
\hline LSD at $5 \%$ & 0.026 & 0.011 & 0.016 & 0.011 \\
\hline
\end{tabular}

CHT= chitosan; $\mathrm{SWE}=$ seaweed extract.

mixture as a foliar spray. In general, the 60 ppm CHT $+1.5 \mathrm{~cm}^{3}$ SWE/l treatment gave the highest values of growth, flowering parameters and bulb production of tuberose (Polianthes tuberosa, L.) plants grown in pots under Dakahlia Governorate conditions.

\section{REFERENCES}

Abbas, M.; Anwar, J.; Zafar-ul-Hye, M.; Khan, R.I.; Saleem, M.; Rahi, A.A.; Danish, S. and Datta, R. (2020). Effect of seaweed extract on productivity and quality attributes of four onion cultivars. Horticulturae, 28(6):1-13.

Alan, O.; Gunen, Y.; Ceylan, S. and Gunen, E. (2007). Effect of nitrogen applications on flower yield, some quality characteristics and leaf mineral content in tuberose (Polianthes tuberosa L.). Journal of Aegean Agric. Res. Inst., 17(1):43-57.

Analytical Software (2008). Statistix Version 9, Analytical Software, Tallahassee, Florida, USA. 
AOAC (1990). Official Methods of Analysis. $15^{\text {th }}$ Ed. Association of Official Analytical Chemists, Inc., Virginia, USA., 1298 p.

Aziz, N.; Mahgoub, M. and Siam, Z. (2011). Growth, flowering and chemical constituents performance of Amaranthus tricolor plants as influenced by seaweed (Ascophyllum nodosum) extract application under salt stress conditions. J. Appl. Sci. Res., 7:1472-1484.

Byczyńska, A. (2018). Chitosan improves growth and bulb yield of pineapple lily (Eucomis bicolor Baker) an ornamental and medicinal plant. World Scientific News, 110:159-171.

Calvo, P.; Nelson, L. and Kloepper, J.W. (2014). Agricultural uses of plant biostimulants. Plant Soil, 383: 3-41.

Chapman, D.H. and Pratt, R.F. (1978). Methods of Analysis for Soils, Plants and Waters. Div. Agric. Sci. Univ. of California, USA, pp. 16-38.

Crouch, I.J.; Smith, M.T.; van Staden, J.; Lewis, M.J. and Hoad, G.V. (1992). Identification of auxins in commercial seaweed concentrates. J. Plant Physiol., 139:590-594

Deepmala, K.; Hemantaranjan, A.; Singh, B. and Bhanu, A.N. (2014). A future perspective in crop protection: Chitosan and its oligosaccharides. Advances in Plants \& Agriculture Research, 1(1):1-6.

Deshmukh, M.R. (2012). Effect of various irrigation methods on growth, flowering and yield of tuberose (Polianthes tuberosa Linn.). J. Hort. Sci., 7(1): 94-97.

Dzung, N.A.; Khanh, V.T.P. and Dzung, T.T. (2011). Research on impact of chitosan oligomers on bio-physical characteristics, growth, development and drought resistance of coffee. Carbohydr. Polym., 84:751-755.

El-Gamal, Seham M.A. and Ahmed, H.M.I. (2016). Optimization coriander production for fruit and essential oil B:
Yield improvement by chitosan and salicylic acid foliar application. J. Plant Production, Mansoura Univ., 7(12):14811488.

El-Khateeb, M.A.; Nasr, A.A.M. and Hassan, N.A.A. (2018). Growth and quality improvement of Dracaena surculosa, Lindl by the foliar application of some bio-stimulants. International Journal of Environment, 7(2):53-64.

El-Sayed, S.G.; Ismail, S.M. and Eissa, D. (2018). Impact of seaweed extract and phosphorus application on productivity of dahlia plants. Assiut J. Agric. Sci., 49(1):159-188.

Ibraheim, S.K.A. and Mohsen, A.A.M. (2015). Effect of chitosan and nitrogen rates on growth and productivity of summer squash plants. Middle East J. Agric. Res., 4(4):673-681.

Malerba, M. and Cerana, R. (2018). Recent advances of chitosan applications in plants. Polymers, 10:1-10.

Rady, H.M.; EL-Mesirry, Dina S. and Aboel-Fadel, Nashwa I. (2018). Quality improvement and seed yield of two garlic cultivars (Allium sativam L.) by seaweed extract and mycorrhizae. Alex. J. Agric. Sci., 63(1):41-51.

Rammamurthy, S.; Venkataraman, S.; Meera, R.S.P.; Chriristina, A.J.M. and Devi, P. (2010). Phytochemical investigation of Polianthes tuberosa. International J. of Pharm. Tech. Research, 2(2):1204-1206.

Ramos-Garcia, M.; Ortega-Centeno, S.; Hernandez-Lauzardo, A.N.; Alia-Tejacal, I. Bosquez-Molina, E. and BautistaBaños, S. (2009). Response of gladiolus (Gladiolus spp) plants after exposure corms to chitosan and hot water treatments. Sci. Hort., 121:480-484.

Salachna, P. and Zawadzińska, A. (2014). Effect of chitosan on plant growth, flowering and corms yield of potted freesia. Journal of Ecological Engineering, 15(3):97-102. 
Salachna, P.; Wilas, J. and Zawadzińska, A. (2015). The effect of chitosan coating of bulbs on the growth and flowering of Ornithogalum saundersiae. Acta Hort., 1104:115-118.

Shafeek, M.R.; Helmy, Y.I. and Omar, Nadia M. (2015). Use of some biostimulants for improving the growth, yield and bulb quality of onion plants (Allium cepa L.) under sandy soil conditions. Middle East Journal of Applied Sciences, 5(1):68-75.

Snedecor, W.G. and Cochran, G.W. (1980). Statistical Methods, $7^{\text {th }}$ Ed., the Iowa State Univ. Press, Ames, Iowa, USA., $507 \mathrm{p}$.
Sowmiya, P. and Karuppaiah, P. (2019). Effect of foliar concoction on growth, yield and quality of jasmine (Jasminum sambac Ait.). Plant Archives, 19(1):435440.

Turan, M. and Kose, C. (2004). Seaweeds extracts improve copper uptake of grapevine. Acta Agriculturae Scandinavica. Section B, Soil and Plant Science 54: 213-220.

Zhang, X.; Ervin, E.H. and Schmidt, E.R. (2003). Plant growth regulators can enhance the recovery of Kentucky bluegrass sod from heat injury. Crop Sci., 43:952-956.

\section{إستجابة نباتات التبروز (الزنبق) للرش الورقي بالثيتوزان ومستخلص الأعشاب البحرية

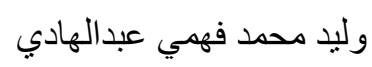 \\ قسم بحوث نباتات الزينة وتنسيق الحدائق، معهد بحوث البساتين، مركز البحوث الزر اعبة، الجيزة، مصر فيدر}

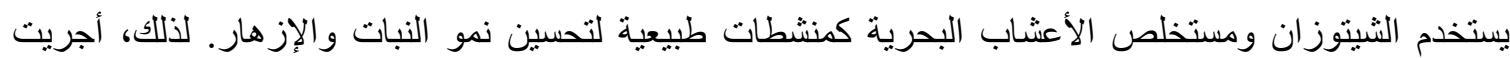

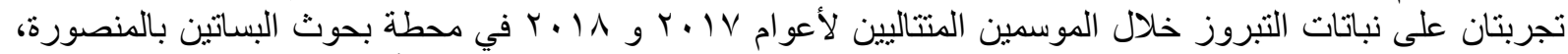

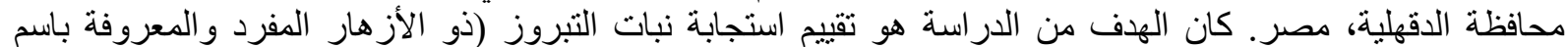

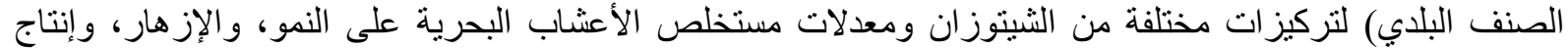

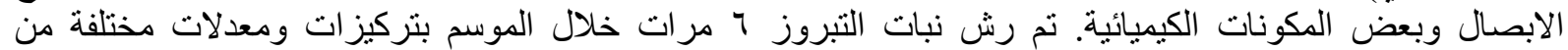

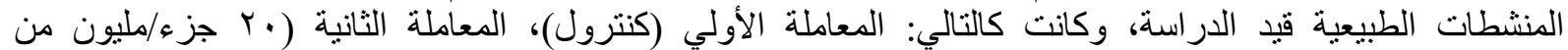

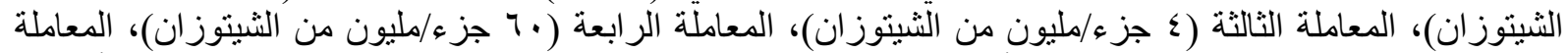

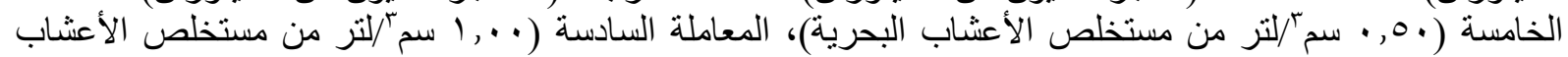

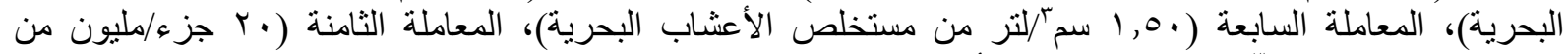

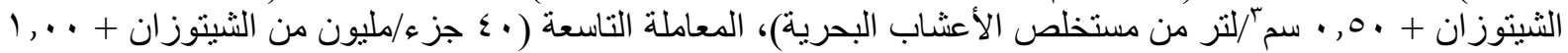

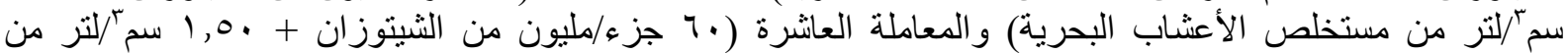

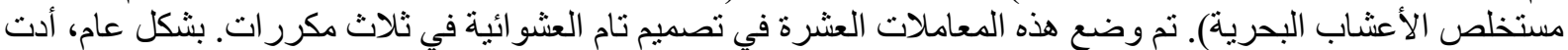

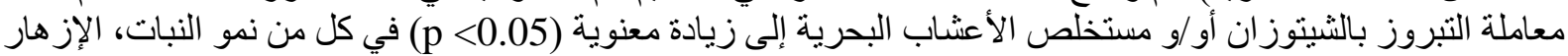

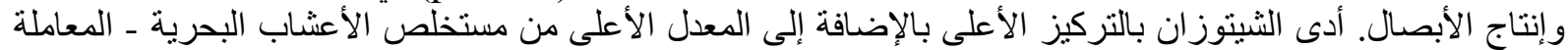

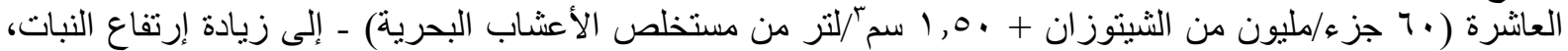

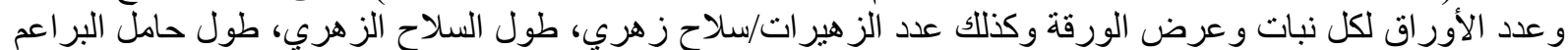

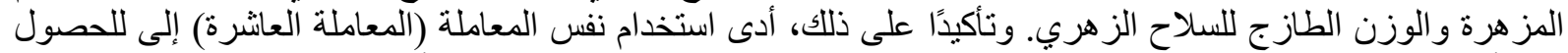

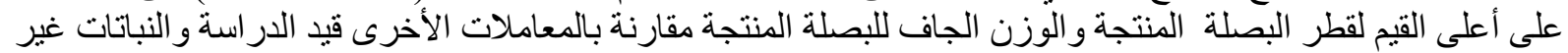

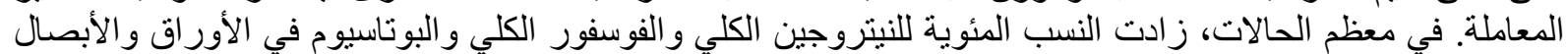

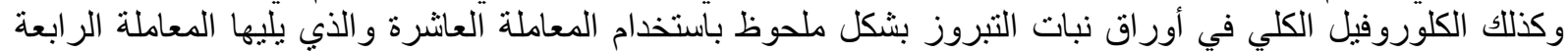

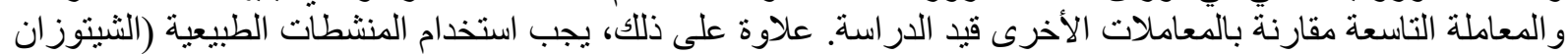
ومستخلص الأعشاب البحرية) بشكل منكرر في المزار عالة للحصول على أفضل نمو وإزهار لنبات التبروز(الزنبق). 